the outside, in order to hold the outer and inner cores in their proper relative positions on removing the wax. Before the completion of the outer core, wax rods or bars, that later form channels for the metal or vents, are attached to the wax figure wherever necessary, all leading to one main channel in the upper end of the mold. The enveloping of the figure with the composition is now completed, and the mold placed in an oven and baked over a slow fire. Under this treat ment the wax runs out, leaving a mold of the com plete figure, while at the same time the composition hardens. The mold is now ready for running the molten metal.

The casts come from the mold in an almost perfect condition, the minutest detail being as clear and dis tinct as if chiseled by hand. Beyond removing the channels and vents, which of course have been fille with metal, and brushing off the particles of the hard ened composition with a stiff brush, the figure require no attention other than the usual final coloring or patining, which is done with acids and chemicals

In the "Cire-perdue," freely translated "lost wax" process as used by the Greeks and Romans, an inne core was made roughly of the desired shape an covered with a layer of wax. In this wax the artis modeled the figure and then the outer core was put on surrounding it. The mold was then baked, the wax melting out, and the metal run in. While this made an exceedingly good bronze of the artist's conception, it did not permit of making more than one and was consequently impracticalule for modern use, till the geniu of Cellini developed the process to its present state.

For the information contained in the above account we are indebted to the courtesy of the Roman Bronze Works, of Greenroint

Brooklyn.

\section{A NOVEL SUSPENSION} BRIDGE

That "necessity is

the mother of inven

tion" is seldom

exemplified than in

the case where man is confronted with an engineering problem with nothing but nature's tools - his hands -to solve it. Grea praise has been forth coming for the genius whose brain evolved the plans of such bridge as the New York and Brooklyn suspension bridge; but would that same skill. which, aided by every facility possible, has produced such mas sive and well-sustain. ed monuments of stone and steel, be equal to the emerg. ency if confronted by

the same problem, though on a diminutive scale, a thousand miles from a machine shop and possibly a hundred from a hammer and nails?

This, however, is the position of the natives in many parts of Mexico and Central America, where fairly wide and rapid-running streams are so numerous that even in some of the miniature republics above the isthmus their water power in the aggregate might compare favorably with that of Niagara. They are never dry and seldom fordable; when swollen by unusual rains they are often absolutely impassable for weeks except by a lofty bridge, and this the native has provided alone and unaided.

The tropical forest supplies lianas of every imagin ble length and diameter, from the quarter-inch tendril to the vine with the girth of a man, and all, bar ring flexibility, with practically the same properties as steel cables. These, with a little rope and the boarding required for the footwalk, which is also supplied by the trees at hand, are all that are required. Work is begun without any controversy as to eyebars or suspension cables, and within a month, more or less-for there is never any hurry-the completed suspension bridge will be gently swinging in the breeze, unique in its freedom from iron or metal fastenings of any nature. A glance at the one shown in the accompanying illustration reveals the fact that with the exception of anchorages, which are entirely lacking, all the principles of the suspension brilge as known to modern practice are in evidence. Stout trees are utilized as towers and form the bridge's sole support. The work throughout is done in the crudest manner and as a rule one must mount several feet into a tree in order to begin the journey. To the un. initiated a trip across one of these brilges is not always an unalloyed pleasure, for it sways uncomfort- ably, sinks with any weight to a rather alarming dere creaking and groaning of its members are far from reassuring. Nevertheless, they are built o last and are not temporary in any sense, occasional repairs being sufficient to maintain them for years. Needless to add, the capacity of one of these bridges is limited to man and his burden; a four-legged animal would have a difficult time crossing.

\section{EXHIBITS IN THE BOILER HOUSE AND THE PALACE OF MACHINERY, ST. LOUIS.}

The purpose of the collection of exhibits in the Palace of Machinery and in the Boiler House, officially known as the Steam, Gas, and Fuel Building, is to show, first, the modern methods for developing and using power, and secondly, the machinery and appa ratus used in making machines.

The Power House and Machinery Building, in spite of the serious omission of several large European gas engines and producers that were contracted for but failed to materialize, is a most interesting field of study. The total fuel consumption averages somewhat over 400 tons per day. To insure that the requis ite amount of fuel should be on hand, the Commis sioner purchased 170 fifty-ton coal cars, which bring the coal direct from the mine to the power house. In order to provide against mishap, a large number of loaded cars are maintained at all times on the sidings, so as to insure that there shall be several days' supply of fuel on hand.

It is a significant fact that the whole of the boiler installation is of the water-tube type. First we have sixteen Babcock \& Wilcox boilers of 400 horse-power

presses, metal-bending and shaping tools, and forge shop requirements are grouped Adjacent to these on one side is a fine display of abrasives and machinery for using abrasives. Next on the opposite side are pumps, air compressors and water meters. Beyon these are the gas and gasoline engines, a display whic is good as iar as it goes, but for reasons above stated gives an altogether inadequate idea of the remarkable development of the art as reached in Europe. To the east of the gas engine department is a collection of belts, pulleys, hangers, and shafting; and then follow hoisting engines, winches, and other applaratus and appliances for lifting heavy bodies. In succession follow pneumatic tools and appliances, fire hose and fire escapes and miscellaneous machinery, until the very interesting woodworking group is reached in the southeast quarter of the building, where several ma chines may be witnessed in operation.

Within the scope of the present article it is im possible to give any detailed account of the numerous exhibits; that has been and will be done in various illustrated articles in this journal. In the present connection we show a series of views taken in both the Boiler House and the Machinery Building. The Westinghouse Company exhibit a Parsons turbine direct-connected to a 400-kilowatt generator. Though it is a comparatively small turbine compared with the powerful units that th is company is building for power station service, it is thoroughly typical of this very interesting development in prime movers. The turbine is running at a speed of 3,600 revolutions per minute and delivers a three-phase, 60-cycle current at a potential of 440 volts.

The fine engine built by the Elsaessische Maschin enbau A.-G. and the 700-kilowatt generator to which it is directconnected, built at Bel fort by the Société Al sacienne de Constructions, deserve all the avorable com ment that they are eliciting. The engine is of 1,000 horse-power. Steam is admitted by trans verse piston valves, carried above the cy linders, one at each end. These are operated by eccentrics, one
eccentric serving to operate both the steam admission and the ex haust. The alternating, three-phase gener ator has a capacity of 700 kilowatts, and a voltage of 2,300 Another exhibit that we illustrate is a Weber suction gas l:ro ducer. It consists of a two-cylincler, uprigli 125 - horse-power en gine, direct-connected

A NOVEL SUSPENSION BRIDGE.

each. Then follow the eight Heine boilers, which are also of 400 horse-power. Aultman \& Taylor are represented by sixteen boilers, eight of them of 500 horse-power, and eight of them of 400 horsepower. Durr is represented by a 700-horse-power boiler that can carry 1,200 horse-power; Niclausse is represented by two 800 horse-power boilers that can carry 1,000 horse-power; Belleville has three boilers of 500 horse-power; Clonbrock one 300-horse-power unit of the marine type and one 250-horse-power stationary boiler. The most modern boiler in the whole installa tion is a Schuette boiler of 500 horse-power manufactured at Stettin. In addition to the boilers them selves there is, of course, all the concomitant plant in the way of blowers, pumps, etc., that is necessary for the running of the plant. Some of these, however, have received separate treatment in this journal and need not be enumerated at the present writing.

To the second object aimed at by the Commissioner in charge of the Machinery Building, namely, the exhibition of machinery and apparatus used in makin machines, about two-thirds of Machinery Hall is de voted. With a few exceptions the exhibits to accomplish similar results are found grouped in and about certain well-defined locations. Thus, means for guiding and controlling the flow of water, steam, and gas are located along or near the northerly wall of the building. Next, and toward the south, are machine for cutting and forming metals; the range of this as sortmen $i$ extending from the huge machines used in ship, engine, and car works, down to the pigmy tools used in watch making. Instruments which will measure to one ten-thousandth part of an inch and tools which do work so accurate as to require such refine. ment in measuring are here exhibited.

Toward the center of the building, power punches, to a 75-kilowatt generator. The unit also comprises a roducer, a scrubber and a receiver. It is entirely automatic, the feed of fuel being regulated according to the requirements of the producer; and the whole plant running with great regularity.

The group of fourteen Worthington fire pumps sulplies the whole fire service of the exhibition grounds. The steam cylinders are 18 inches, the water cylinder 10 inches in diameter, and the common strolie is 12 inches. The battery of Cahall watertube boilers is exhilbited by the Aultman \& Taylor Company, who have contributed sixteen boilers of 400 and 500 horse-rower to the boiler house plant. The Willans central-valve, high-speed engine is represented by a 1,000 horse-power unit which is running at 277 revolutions per minute. It is direct-connected to a 600 -kilowatt Stanley generator. The engine is of the single-acting type, and runs under a working pressure of 175 pounds to the square inch.

The veneer-cutting machine shown carries the log between centers on which it rotates, and the veneer is cut by a knife held in a horizontal rest-in other words, the veneer sheet is "turned" off the $\log$, and is nothing more nor less than a mammoth shaving sev. eral feet in width and length.

One of the "big" things in the Machinery Build:ag is a huge 20-foot boring and turning mill that weigh: no less than 375.000 pounds. The central boring bar and gear are carried on two massive columns. The machine is driven by Bullock motors, that for the main lrive being of 80 horse-power and that for elevating the cross-rail of 10 horse-power. The Niles Company lo not share the rather prevalent prejudice against any but a positive drive; for this great machine is driven by the friction feed shown in the foreground of the illustration. 